concerned, is that the courts can always apply the general method of measurement that is commonly used by them in determining the meaning of other defining words. This method consists in the use of the meaning commonly accepted by the masses of the people. For example, if the word "pure" as applied to water means "free from sewage" in the minds of the masses of the people, and this feeling is so strong that the masses of the people prefer to drink a water free from sewage to a water that has been contaminated with sewage, the courts will accept this attitude of the people as a proper means of determining the significance of the word "pure" as applied to water. The degree of importance that must be attached to the element of decency as it relates to any particular thing can at any time be determined by testing public sentiment on this subject.

What attitude should the leaders in public health science take with regard to decency as a public health factor? Shall they encourage the development of the sense of decency on the part of the public as a desirable thing, and as something that can be applied to public and private environment, and to food and drink, in a way so practical that a reasonable degree of decency can be enforced by public officials? Or shall the leaders in public health science conclude that decency is academic, and that the esthetic sense has no place in the list of considerations on which the activities of public health officials are based? If health means more than life, if health includes the enjoyment of life, if health is to include the enjoyment of one's environment, and the enjoyment of things one eats and drinks, then public health administration cannot ignore the demands of common decency in the steps that it takes to safeguard public health.

The progress of the people toward better things seems to be constantly marked by improved sanitation. Public sanitation and private sanitation contribute directly and indirectly in so many ways to better living, better thinking and better working that they seem to be an essential part of the process of development. Whether or not the workers in public health science recognize decency as an important factor in public health science, the common people themselves have already given decency such recognition. The reason the instinct for cleanliness and decency has developed with the race is that these contribute in a marked degree to the satisfaction of living. If public health includes anything more than the element of safety, then decency for its own sake deserves a place in the catalogue of public health administrators.

30 Church Street.

Marching.-While the present war especially in the western regions has involved much trench fighting, besieging, etc., it must be borne in mind that marching still occupies much of the soldier's time, much more than does combat. This is clearly seen in the Russian campaigns. For this reason it is of prime importance that the soldier be able to march well. The general public have a mistaken idea of the length of a heavy march, the tendency being to place the estimate altogether too high. A fair day's marching for any army is 12 miles. The strenuousness of the march depends to a large extent on the size of the marching force. A good day's march consists of 15 miles while 20 constitutes a forced march. Quick time for the English armies consists in about 120, 30 -inch steps per minute, which gives 100 yards per minute. From $2 \frac{1}{2}$ to 3 miles per hour is good marching. It takes a brigade six hours to march 15 miles while a division needs eight for the same distance.-Hygiene and War, by George Ellis Jones, Ph.D.

\section{TREATMENT OF CHANCROID *}

FREDERICK W. ROBBINS, M.D.

Fellow of the American College of Surgeons AND

FRANK P. SEABURY, M.D. DETROIT

We recognize four clinical varieties of chancroid:

1. Ulcus molle, the ordinary variety of ulcer, has the characteristic punched-out appearance, with edges cleancut and often undermined.

2. Ulcus molle miliare begins as a small papule, which rapidly becomes a pustule, the center of which is a deep craterlike ulcer. It occurs most frequently on exposed surfaces in the loose skin, just posterior to the mucocutaneous junction of the prepuce in man and about the labia majora and the perineum in woman.

3. Ulcus molle elevatum is the sore most frequently confused with indurated chancre. Its incubation period is from nine to twenty-one days. The sore is slightly raised above a mildly infiltrated base. The edges are not undermined, and it has little tendency to spread. This form is resistant to ordinary treatment and is prone to persist for from four to eight weeks.

4. Ulcus molle phagedenicum is the most severe and the most resistant form with which we are familiar, and occurs as a complication of both chancroid and syphilis. It spreads rapidly, is made worse by any half-way measures, and, unless checked early, is capable of destroying a part or even the whole of the penis.

To these McDonagh adds a fifth classification, the ulcus molle serpiginosum. This ulcer may occur as a complication of bubo or it may begin as a furuncle in the groin. It is found chiefly in the tropics, is highly resistant to all forms of treatment, and frequently remains a slowly spreading ulcer for years. We have never encountered it in this country.

The treatment of chancroid, at the best, is unsatisfactory, as is evidenced by the great variety in the methods of treatment advocated by different authors. If seen early, a fair percentage of patients do well under nearly any antiseptic treatment, particularly if they are cleanly in their habits. In fact, we believe that 60 per cent. of chancroids, taken as they come, of anywhere from two days to two months' duration, will heal in from four to eight weeks with no treatment except rigid cleanliness, a little calomel, or other dusting powder, if the sore is within the preputial cavity, or a moist dressing of black wash if the sore is exposed. If seen within the first two or three days, thorough cauterization with nitric acid is quite successful, but great care must be used not only to destroy completely every sore, but to keep the surrounding tissue covered with an antiseptic until healing of the cauterized areas is complete.

It is the sores that are not seen early, or that are not favorably influenced by cauterization, which cause the trouble and for which we have never been able to find in the literature a thoroughly satisfactory method of treatment.

Zinc ionization gives good results, but requires special apparatus and consumes considerable time. Argyrol crystals applied directly to the sore for three

* Read before the Section on Genito-Urinary Diseases at the Sixty. Eighth Annual Session of the Americar Medical Association, New York, June, 1917. 
or four minutes, followed by a moist dressing of 10 per cent. argyrol or 1 per cent. protargol, have been satisfactory in a few cases; in others they have not even checked the spreading of the ulcer.

A satisfactory method of treatment for the large majority of cases of chancroid in the preputial cavity is the thorough application of a 25 per cent. solution of copper sulphate crystals in water. The ulcer is first anesthetized with a 10 per cent. cocain solution and then lightly curetted with an applicator wound firmly with cotton, after which the copper solution is applied. It is left in contact with the sore for three
In order that a method of treatment of chancroids may be regarded as satisfactory, it must not only effect a complete sterilization of the sore and thereby a cure of practically all cases within a reasonable length of time, but in order to be available to the large majority of physicians, it must also be comparatively simple in form and means of application. Such a method, or combination of methods, we believe we have devised, and we base our conclusions on the observation of about sixty cases during the past year. In this series we have had practically 100 per cent. of early cures.

RESULTS OF AUTHORS' METHOD OF TREATMEN' IN THIRTY-FOUR CASFS

\begin{tabular}{|c|c|c|c|c|c|c|c|c|c|c|c|}
\hline $\begin{array}{l}\text { Case } \\
\text { No. }\end{array}$ & $\begin{array}{l}\text { No, of } \\
\text { Lesions }\end{array}$ & $\underset{\text { Period }}{\text { Incubation }}$ & $\begin{array}{l}\text { Previous } \\
\text { Treatment }\end{array}$ & $\begin{array}{l}\text { Duration } \\
\text { Before } \\
\text { Fulgura- } \\
\text { tion }\end{array}$ & $\begin{array}{l}\text { Darkfleld } \\
\text { or Stain }\end{array}$ & $\begin{array}{l}\text { Diag- } \\
\text { nosis* }\end{array}$ & $\begin{array}{l}\text { Number } \\
\text { of Treat- } \\
\text { ments with } \\
\text { Violet Ray }\end{array}$ & Healed & Bubo & $\begin{array}{l}\text { Wasser- } \\
\text { mann }\end{array}$ & Remarks \\
\hline$\frac{1}{2}$ & $\begin{array}{l}1 \\
2\end{array}$ & $\begin{array}{l}7 \text { days } \\
13 \text { days }\end{array}$ & $\begin{array}{l}\text { No } \\
\text { Argyrol dust- } \\
\text { ing powder }\end{array}$ & $\begin{array}{l}2 \text { weeks } \\
2 \text { months }\end{array}$ & $\begin{array}{l}\text { Negative } \\
\text { Negative }\end{array}$ & $\begin{array}{l}\text { U. M. } \\
\text { U. M. M. }\end{array}$ & $\begin{array}{l}\text { One } \\
\text { One }\end{array}$ & $\begin{array}{l}8 \text { days } \\
9 \text { days }\end{array}$ & No $\stackrel{\text { No }}{\text { Yet opened }}$ & $\begin{array}{l}\text { None } \\
\text { Negative }\end{array}$ & Bubo subsided \\
\hline $\begin{array}{l}3 \\
4\end{array}$ & $\begin{array}{l}1 \\
3\end{array}$ & $\begin{array}{l}7-8 \text { days } \\
7 \text { days }\end{array}$ & $\begin{array}{c}\text { Argyrol crys. } \\
\text { No }\end{array}$ & $\begin{array}{l}4 \text { weeks } \\
1 \text { day }\end{array}$ & $\begin{array}{l}\text { Not made } \\
\text { Negative }\end{array}$ & $\begin{array}{l}\text { U. } \mathbf{M} \text {. } \\
\text { N. M. }\end{array}$ & $\begin{array}{l}\text { One } \\
\text { One }\end{array}$ & $\begin{array}{l}7 \text { days } \\
11 \text { days }\end{array}$ & $\begin{array}{l}\text { No } \\
\text { No }\end{array}$ & $\begin{array}{l}\text { None } \\
\text { Negative }\end{array}$ & $\begin{array}{l}2 \text { or } 3 \text { sores healed } \\
\text { in } 4 \text { days }\end{array}$ \\
\hline 5 & 2 & 4 days & $\begin{array}{c}\text { Caustic argyrol } \\
\text { and violet ray }\end{array}$ & 6 weeks & Negative & U. M. M. & One & 7 days & No & None & Exposed sore \\
\hline 6 & 1 & 4-5 days & $\begin{array}{c}\text { Caustic aristol } \\
\text { argyrol }\end{array}$ & 5 weeks & Negative & U. M. & One & 9 days & No & None & Exposed sore \\
\hline 7 & 1 & Indefinite & None & 3 weeks & Negative & Chancre & On: & 5 days & No & None & $\begin{array}{l}\text { Hard chancre devel. } \\
\text { oped at site of sore }\end{array}$ \\
\hline $\begin{array}{r}8 \\
6 \\
10 \\
11 \\
12\end{array}$ & $\begin{array}{l}4 \\
1 \\
1 \\
2 \\
1\end{array}$ & $\begin{array}{l}\text { 4 days } \\
\text { 10-12 days } \\
\text { Indefinite } \\
\text { Indefnite } \\
\text { Indefinite }\end{array}$ & $\begin{array}{c}\text { Antiseptic wash } \\
\text { None } \\
\text { None } \\
\text { None } \\
\text { Salve }\end{array}$ & $\begin{array}{l}3 \text { weeks } \\
12 \text { days } \\
4 \text { days } \\
17 \text { days } \\
7 \text { days }\end{array}$ & $\begin{array}{l}\text { Not marde } \\
\text { Negative } \\
\text { Negative } \\
\text { Negative } \\
\text { Negative }\end{array}$ & $\begin{array}{l}\text { U. M. } \\
\text { U. M. j. } \\
\text { U. M. } \\
\text { U. M. M. } \\
\text { Chancre }\end{array}$ & $\begin{array}{l}\text { One } \\
\text { One } \\
\text { One } \\
\text { Three } \\
\text { 'Two }\end{array}$ & $\begin{array}{l}5 \text { days } \\
5 \text { drys } \\
4 \text { days } \\
16 \text { days } \\
14 \text { days. not } \\
\text { heaied }\end{array}$ & $\begin{array}{c}\text { No } \\
\text { No } \\
\text { No } \\
\text { Yes, not opened } \\
\text { No }\end{array}$ & $\begin{array}{l}\text { None } \\
\text { None } \\
\text { None } \\
\text { Negative } \\
\text { Positive }\end{array}$ & \\
\hline 13 & 2 & 2 weeks & $\begin{array}{l}\text { Caustic and } \\
\text { calomel }\end{array}$ & 2 weeks & Negative & U. M. E. & One & 6 days & No & None & $\begin{array}{l}\text { Circumcised } 2 \text { days } \\
\text { after healing: } 1 / 2 \\
\text { circumference be- } \\
\text { came chancroidal, } \\
\text { healed in } 2 \text { weeks }\end{array}$ \\
\hline $\begin{array}{l}14 \\
11\end{array}$ & $\begin{array}{l}1 \\
1\end{array}$ & $\begin{array}{l}\text { Indefinite } \\
10 \text { days }\end{array}$ & $\begin{array}{c}\text { None } \\
\text { Dusting pow. }\end{array}$ & $\begin{array}{l}3 \text { days } \\
7 \text { days }\end{array}$ & $\begin{array}{l}\text { Negative } \\
\text { Refused }\end{array}$ & $\begin{array}{l}\text { U. M. } \\
\text { U. M. F. }\end{array}$ & $\begin{array}{l}\text { One } \\
\text { One }\end{array}$ & $\begin{array}{l}5 \text { days } \\
6 \text { days }\end{array}$ & $\begin{array}{l}\text { No } \\
\text { No }\end{array}$ & $\begin{array}{c}\text { None } \\
\text { Refused }\end{array}$ & \\
\hline $\begin{array}{l}16 \\
17\end{array}$ & 1 & $\begin{array}{l}\text { Indefinite } \\
9 \text { days }\end{array}$ & $\begin{array}{l}\text { None } \\
\text { None }\end{array}$ & $\begin{array}{l}8 \text { days } \\
1 \text { day }\end{array}$ & $\begin{array}{l}\text { Negative } \\
\text { Negative }\end{array}$ & $\begin{array}{l}\text { U. M. M. } \\
\text { U. M. }\end{array}$ & $\begin{array}{l}\text { One } \\
\text { One }\end{array}$ & $\begin{array}{l}7 \text { days } \\
6 \text { days }\end{array}$ & $\begin{array}{l}\text { No } \\
\text { No }\end{array}$ & $\begin{array}{l}\text { None } \\
++t\end{array}$ & Hard chancre devel- \\
\hline $\begin{array}{l}18 \\
19\end{array}$ & $\begin{array}{l}1 \\
1\end{array}$ & $\begin{array}{l}\text { Indeflnite } \\
4-5 \text { days }\end{array}$ & $\begin{array}{l}\text { None } \\
\text { None }\end{array}$ & $\begin{array}{l}10 \text { days } \\
7 \text { days }\end{array}$ & $\begin{array}{l}\text { Negative } \\
\text { Negative }\end{array}$ & $\begin{array}{l}\text { U. M. } \\
\text { U. M. M. }\end{array}$ & $\begin{array}{l}\text { One } \\
\text { I'wo }\end{array}$ & $\begin{array}{l}5 \text { days } \\
14 \text { days }\end{array}$ & $\begin{array}{l}\text { No } \\
\text { Yes }\end{array}$ & $\begin{array}{l}\text { None } \\
\text { None }\end{array}$ & $\begin{array}{l}\text { oped at site of sore } \\
\text { Bubo incised, healed } \\
\text { slowly; applied } \\
\text { CuSO; and violet } \\
\text { ray, healed rapidlly }\end{array}$ \\
\hline 90 & 4 & $9-10$ days & Calomel & 3 weeks & Not made & U. M. E. & Two & 9 days & Yes, subsided & Refused & \\
\hline 21 & 3 & 1078 & Antiseptic & 6 weeks & Refused & U. M. P. & Three & 25 days & No & Refused & $\begin{array}{l}\text { Phagoclinic case; } \\
\text { patient very un- } \\
\text { cleanly }\end{array}$ \\
\hline$\frac{22}{23}$ & $\begin{array}{l}1 \\
2\end{array}$ & $\begin{array}{c}12-13 \\
\text { Indefinite }\end{array}$ & $\begin{array}{l}\text { Antiseptic } \\
\text { None }\end{array}$ & $\begin{array}{l}8 \text { days } \\
2 \text { weeks }\end{array}$ & $\begin{array}{l}\text { Negative } \\
\text { Negative }\end{array}$ & $\begin{array}{l}\text { U. M. M. } \\
\text { U. M. }\end{array}$ & $\begin{array}{l}\text { One } \\
\text { One }\end{array}$ & $\begin{array}{c}5 \text { days } \\
10 \text { days nearly }\end{array}$ & $\begin{array}{l}\text { No } \\
\text { Yes }\end{array}$ & $\begin{array}{l}\text { None } \\
\text { None }\end{array}$ & \\
\hline$\underline{94}$ & 1 & Inclefinite & $?$ & 2 months & No & U. $\mathbf{M}$. & 'Two & 5 days nearly & Yes, incised & Negative & $\begin{array}{l}\text { Nearly healed on 5th } \\
\text { day; not seen after- } \\
\text { ward }\end{array}$ \\
\hline 25 & 2 & Indefinite & None & 10 days & Negative & U. M. & One & 10 days & No & $\begin{array}{l}++++(2 \\
\text { wks. later })\end{array}$ & \\
\hline$\frac{96}{7}$ & $\begin{array}{l}3 \\
2\end{array}$ & $\begin{array}{l}2 \text { weeks } \\
5 \text { days }\end{array}$ & $\begin{array}{l}\text { Ointment } \\
\text { None }\end{array}$ & $\begin{array}{l}4 \text { weeks } \\
3-4 \text { days }\end{array}$ & $\begin{array}{l}\text { None } \\
\text { None }\end{array}$ & U. M. & $\begin{array}{l}\text { Two } \\
\text { One }\end{array}$ & & No & $\begin{array}{l}\text { None } \\
\text { None }\end{array}$ & \\
\hline 89 & $\begin{array}{l}1 \\
1\end{array}$ & $\begin{array}{l}2 \text { weeks } \\
10 \text { days }\end{array}$ & $\stackrel{?}{\text { None }}$ & $\begin{array}{l}5 \text { days } \\
2 \text { days }\end{array}$ & $\begin{array}{l}\text { Negative } \\
\text { Negative }\end{array}$ & U. M. M. & $\begin{array}{l}\text { Cne } \\
\text { One }\end{array}$ & $\begin{array}{l}6 \text { days } \\
6 \text { days }\end{array}$ & $\begin{array}{l}\text { No } \\
\text { No }\end{array}$ & $\begin{array}{l}\text { None } \\
\text {......... }\end{array}$ & $\begin{array}{l}\text { Has been sent for } \\
\text { Wassermann test: } \\
\text { think there is a } \\
\text { hard chancre at } \\
\text { meatus }\end{array}$ \\
\hline $\begin{array}{l}20 \\
11\end{array}$ & $\begin{array}{l}3 \\
1\end{array}$ & $\begin{array}{l}4 \text { days } \\
5 \text { days }\end{array}$ & $\begin{array}{l}\text { Calomel } \\
\text { None }\end{array}$ & $\begin{array}{l}\text { I4 days } \\
3 \text { days }\end{array}$ & $\begin{array}{l}\text { Negative } \\
\text { Negative }\end{array}$ & $\begin{array}{c}\mathrm{U} . \mathbf{M} . \mathbf{E} . \\
\text { U. }\end{array}$ & $\begin{array}{l}\text { Two } \\
\text { One }\end{array}$ & $\begin{array}{l}7 \text { days } \\
4 \text { days }\end{array}$ & $\begin{array}{l}\text { No } \\
\text { No }\end{array}$ & $\begin{array}{l}\text { None } \\
\text { None }\end{array}$ & \\
\hline 32 & $\frac{2}{5}$ & $\begin{array}{l}\text { Indefinite } \\
\text { Indefinite }\end{array}$ & $\begin{array}{c}\text { None } \\
\text { Calomel }\end{array}$ & 11 days & $\begin{array}{l}\text { Negative } \\
\text { Yegative }\end{array}$ & $\begin{array}{l}\text { U. } \mathbf{M} . \\
\text { U. }\end{array}$ & $\begin{array}{l}\text { Two } \\
\text { Two }\end{array}$ & 7 days & $\begin{array}{l}\text { No } \\
\text { Yes, subsided }\end{array}$ & $\begin{array}{l}\text { None } \\
\text { None }\end{array}$ & \\
\hline $\begin{array}{l}33 \\
34\end{array}$ & $\begin{array}{l}5 \\
1\end{array}$ & Inciefinite & $\begin{array}{l}\text { Calomel } \\
\text { Aristol }\end{array}$ & $\begin{array}{l}8 \text { days } \\
2 \text { weeks }\end{array}$ & $\begin{array}{l}\text { Negative } \\
\text { Negative }\end{array}$ & & Three & $\begin{array}{l}\text { I2 days, not } \\
\text { he led }\end{array}$ & No & Positive & \\
\hline
\end{tabular}

* Numes in diagnosis column: U. M., Uleus molle; U. M. M., Uleus molle miliare; U. M. F., Ulcus molle elevatum; U. M. P., Uleus molle phagedenir

or four minutes and then sponged off. On the dry sore a light dusting powder, calomel or a morphinnarcotin mixture is used, and one or two thicknesses of gauze, moistened with black wash or tap water, are applied and the foreskin drawn forward over the whole. This is changed two or three times daily; and every second day, unless granulation is progressing satisfactorily, a 10 per cent. solution of copper sulphate is applied. The majority of chancroid ulcers do well under this treatment, but from 15 to 20 per cent. tend either to persist many weeks, or to grow gradually larger and deeper in spite of treatment. The direct cause is the failure to sterilize the wound.
Regardless of the appearance, duration or previous treatment of a venereal sore before it is destroyed, it is always examined for spirochetes.

If antiseptics have been used, it is our custom to apply a moist dressing of cotton wet with tap water for from twenty-four to seventy-two hours, during which time two or three microscopic examinations are made. If no treatment has been previously given, the examination and destruction of the sore is accomplished at the first visit.

A small pledget of cotton is wet with 10 to 20 per cent. solution of cocain and applied to each lesion. After four or five minutes the field is carefully 
cleansed with soap and water and dried. Each lesion is then thoroughly wiped out with a cotton wound applicator until bleeding ensues. This is arrested by sponging, and when only serum exudes from the wound, this is collected for examination by dark field or stain, as may be the choice of the operator.

A 25 per cent. solution of copper sulphate in distilled water is now applied to the sore, and the short high frequency spark from a rather fine-pointed vacuum electrode is applied directly to the sore for one to three minutes, depending on the extent of the ulceration. Especial care is exercised in carrying the point of the electrode well down into any fissure or undermined edge, and the area of application should extend over the edge of the sore about one sixteenth inch into the doubtfully healthy area.

The current is not turned off until every crack and crevice has been thoroughly treated and the surface of the sore is changed to a dark greenish gray. It is then wiped dry and some antiseptic powder is lightly applied to the entire mucous surface of the preputial cavity. If the sore is exposed, it should be covered with a thick moist dressing, for which any very dilute antiseptic solution may be used, as a $1: 10,000$ or $1: 20,000$ mercuric chlorid solution; or even tap water answers nicely in most cases. This should be changed once or twice daily, and must not be allowed to stick.

The patient is instructed to return in two days, and, if the work has been carefully done, the wound will present a perfectly healthy granulation that will go on to complete healing in a few days. If the sore does not look clean, the application is repeated at the second visit. The patient returns each second day. If the original sore was large, or if a small sore does not seem to be closing rapidly, we have made it a practice to apply, at each visit, either a 10 per cent. copper sulphate or a 5 per cent. silver nitrate solution. We do not hesitate to repeat the original cauterization at any time we have reason to think the chancroidal infection is not completely eliminated.

The complete success of this, as of any other method, is dependent on careful, thorough work. There is more danger of too little cauterization than of too much, and thorough cleansing at the time the sore is destroyed must not be forgotten. Again, the after-care, especially with ulcus molle outside the preputial cavity, and with ulcus molle miliare, is of the utmost importance. If one fails to carry the electrode to the bottom of the cavernous ulcer, then one is lost. It heals over the surface, and in two or three days breaks out anew, larger and deeper than before.

If the dressing on an exposed surface is not changed once daily, and moistened at least three or four times, in many cases one will not succeed.

The accompanying table gives our results in all cases in which data are complete. A number of patients failed to return after the first treatment. Several of these have been seen later, and reported uneventful healing in a few days. In no case have we been able to record a failure.

Three or four cases in which the lesions did not incal well or recurred later developed a positive Wassermann reaction, notwithstanding the fact that careful microscopic examination was negative for spirochetes.

To be thoroughly scientific, one should always be able to explain and prove the modus operandi of any treatiment presented to the profession. Unfortunately, we are not able to do just that, but we believe that by this combined treatment we have been able to produce deep sterilization of the chancroid ulcer with a certainty not heretofore effected. This has been done with great satisfaction to ourselves and our patients. We present the method with the hope that our friends may find in its application the same assurance of success that we enjoy.

1212 Kresge Building.

\section{ABSTRACT OF DISCUSSION}

Dr. Noah E. Aronstam, Detroit: The method of procedure in the treatment of chancroids as outlined by the essayists is neither novel nor unique. Old French authors on the subject as far back as 1880 advocated the use of strong solutions of copper sulphate. In the Allgemeine Krankenhaus of Vienna the same method was pursued twenty-five years ago. In the issue of 1902 of the Russkiy Vratch a similar method was mentioned.

The use of the high frequency tube on the lesions after the preliminary cauterization with copper sulphate is somewhat obscure and questionable to me. A pellicle is formed after such procedure on the sore, and hence the violet ray is unable to diffuse or penetrate and thus sterilize the lesion. My experience has been that it requires an untreated and unmolested lesion in order that the ray may prove efficacious.

As regards the varieties of chancroids, I am in the habit of classifying them as follows: (1) simple erosive chancroid; (2) miliary ulcer, or ulcus erosive miliare; (3) serpiginous form; (4) phagedenic; (5) pultaceous or necrotic; (6) gangrenous.

In the last four varieties the prognosis is unfavorable; the lesions prove very obstinate. Even in the simple variety a definite prognosis cannot always be ventured, and we should be guarded in expressing a decided opinion. There is no uniform method by which we can accomplish results. In my hands equal parts of phenol and iodin have proved useful. I refrain from using such caustic agents as strong solutions of silver nitrate, nitric acid and the methods promulgated by the authors for fear of inducing an indurated condition which may closely resemble the primary lesion of syphilis and thus mask and obscure the clinical features of the sore.

I wish to lay stress on the employment of bacterins in chancroidal lesions. I use a mixed staphylococcus vaccine, as frequently the chancroid harbors a mixed infection, superimposed on its causative agent, the Ducrey-Unna bacillus. I also desire to object to the term "chancroid." It should be changed to infective venereal ulcer, and the inadequate and antiquated term "chancroid" should be abolished.

Dr. H. L. Kretschmer, Chicago: The results that Dr. Robbins obtained with his combination treatment are better than the resuits we have obtained. We have been using the copper in 25 per cent. solution, preceded by 95 per cent. phenol, then applying the wet dressings just as he has done; that has given us very satisfactory results. I should like to ask Dr. Robbins how much of his good results he attributes to the action of the caustics and how much to the action of the high frequency current. I should like to ask whether or not in any of the cases of multiple chancroids he cauterized some of the lesions with copper and used high frequency, and treated some with the high frequency alone.

Dr. Charles W. Bethune, Buffalo: I should like to ask Dr. Robbins whether he obtained his high frequency current from the regular, standard high frequency machine which we use in fulguration, or from one of these small machines costing about $\$ 35$. Is the latter sufficient to cause the penetration of the copper sulphate?

Dr. Robbins mentioned the use of mercurials in the treatment of chancroids. One can never tell absolutely that there is not a double infection with the spirochete. In that case one may mask the secondaries, possibly the general adenitis, and very probably the Wassermann reaction.

Dr. B. S. Barringer, New York: Dr. Livermore of Memphis, Tenn., sometime ago suggested that an ounce of argyrol 
crystals would cure all the chancroids in the United States, if properly applied. That was a rather vigorous statement, but we at Bellevue startcd to use the argyrol treatment. The ideal way that we found to use it was to cocainize the chancroid first and put argyrol crystals directly on it. Our results have been so good that we have practically given up every other form of treatment. We are rather inclined to agree with the gentleman who first published this statement.

Dr. Leland J. Boogher, St. Louis: This subject has been the bite noire of all of us. I have secn some cases that I did not believe any form of treatment would touch, and I remcmber one or two cases that ran on for a year or two until the tissue was almost cntirely denuded. I have used crystals of argyrol and also another proprietary silver preparation. There are some cases in which I would like very much to have Dr. Robbins try his form of treatment. I have one such patient now, whom I have been treating about three months, and he is getting worse every day.

Dr. G. G. Smith, Boston: No one has yet mentioned the use of the actual cautery for very severe forms of chancroid, and I should like to mention it as having been in our hands a real weapon of reliance in cases which were not to be cured by applications of phenol, nitric acid and other caustics. We have had to anesthetize the patient either locally or by gas, and then apply the actual cautery until the whole thing is burned out to a dry crisp. I have seen some chancroids which resisted one treatment of that kind, but a second treatment always cured them.

Dr. Irwin E. Colgin, Waco, Texas: I have used a high frequency spark, using an electrode which approached the roentgen ray, and have had some very good results, but I think Dr. Robbins' method is superior to this, due to the fact that the copper in 25 per cent. solution will act as a conductor. The ordinary effleuve from a high frequency electrode, using a long spark, cauterizes the surface, and I do not doubt that using an electrode in conjunction with the copper sulphate in 25 per cent. solution would cause the current to be carried to a greater depth and would sterilize deeper than if the electrode were used by itself.

Dr. F. W. Robrixs, Detroit: In this class of cases we have tried copper sulphate. Dr. Morton's use of zinc chlorid, high frequency--all these various things alone, without unusual results. Is there any one here who has not seen a clironic nicer of the inguinal region, after a bubo has been opened, that has run on and on, the patients looking tuberculous and the condition continuing in spite of everything done? One such patient was in the hospital and in hed from four to six weeks. We used argyrol crystals and tried to cleanse that wound as thoroughly as possible, but without success as far as results were concerned; the patient simply remained in the same condition with this miserable sore that would not heal. Within a week after combined treatment was instiinted the ulcer had healed and he was well.

Dr. Aronstam mentions the former use of copper; that is all right; but whether they used any strong metalic caustic in connection with the high frequency I very much doulst, hecause in those days they had no knowledge of high frequency or violet rays.

As to the machine from which we oltained this current, I use the Wappler larger hattery; Dr. Sealoury uses the smaller portable one. One is just as effectual as the other.

Insurance Company Studies Automobile Fatalities.-The Metropolitan Life Insurance Company has made a statistical study of the death rate from automobile accidents which discloses the fact that the mortality rate from automohile accidents has more than trebled since 1911. In 1911 the death rate from this cause was 2.3 per hundred thousand; in 1916 , it increased to 7.4. The rate for 1916 shows an increase of more than 37 per cent. over that of 1915 . Nearly one third of those killed are children under 10 years of age. Another condition developed by this study is the faci that so far as the industrial population is concerned, more deaths are caused by automobiles than by surface cars, subway trains, elevated trains, bicycles and horse-drawn vehicles combined.

\section{A MORE DELICATE WASSERMANN REACTION DEPENDING ON THE USE OF INCREASED QUANTI- TIES OF BLOOD SERUM *}

\author{
P. T. BOHAN, M.D. \\ $A N D$ \\ L. A. LYNCH, M.D. \\ KANSAS CITY, MO.
}

This paper is based on observations made on 200 patients examined serologically for evidences of syphilis. The work done has covered a period of one and one-half years. The material was obtained from the medical wards of St. Margaret's Hospital. The data given represent our effort to develop a Wassermann technic which would check up in a larger percentage of cases with the clinical diagnosis of syphilis and which would enable us to attach some significance to the negative Wassermann reaction.

Our method consists essentially in the use of graded increasing amounts of blood serum and spinal fluid, each sertum being tested in the following amounts: 0.1 c.c., 0.3 c.c., 0.5 c.c. and 1 c.c., while amounts of spinal fluid as high as 10 c.c. are used in a single test.

Our investigation shows that as much as 1 c.c. of serum may be safely used, and that a negative reaction with 0.1 or 0.2 c.c. of serum is of little or no value in excluding syphilis in the latent or inactive stage, such as locomotor ataxia. In the cases here reported, which required the use of increased amounts of serum to obtain a positive reaction, the diagnosis of syphilis could be made by other means, such as a history of chancre, the clinical findings and by tests of the spinal fluid. In fact, in not a single case that gave a positive reaction only when as much as 1 c.c. was used did we fail to obtain positive findings in the spinal fluid, such as a positive globulin test, a typical colloidal gold chlorid test, as well as a positive Wassermann reaction when a sufficient amount of fluid was used. Seldom, however, was it necessary to use to exceed 5 c.c. of spinal fluid.

Lange, ${ }^{1}$ in 1912 , was using as high as 10 c.c. of spinal fluid for a single reaction, but he was not using large amounts of blood serum. Kromayer and Trinchese ${ }^{2}$ were using as high as 0.4 c.c. of blood serum in 1913, obtaining more specific results than with the smaller amounts.

We have tested over 2,500 blood serums in amounts as high as 1 c.c. This report is made on but 200 , which we checked up by a complete examination of the spinal fluid, a complete clinical history and a careful physical examination.

Of the 200 cases, 143 were known syphilitic. There were forty-one cases of paresis, forty-eight of tabes dorsalis, twenty-nine of cerebrospinal syphilis, seven of congenital syphilis and eighteen cases of syphilitic heart involvement. Eighty-three of these gave complete inhibition of hemolysis with 0.1 c.c. of blood serum; twenty-two gave partial inhibition when 0.3 or 0.5 c.c. was used. In fifteen there was no inhibition until done with 0.5 c.c., and in eighteen cases it was necessary to use 1 c.c. before any degree of inhibition was noted. Six blood serums were negative when 1

* Read before the Section on Pathology and Physiology at the Sixty-Eighth Annual Session of the American Medical Association, New York, June, 1917

1. Lange: Berl. klin. Wchnschr., 1912.

2. Kromayer and Trinchese: Med. Klin., 1912, 8, 404. 